\begin{tabular}{|c|c|c|c|}
\hline${ }_{\mathrm{O}} \mathrm{SMANIYE}_{K_{\mathrm{O}}}$ & $\begin{array}{l}\text { OKU Fen Bilimleri Enstitüsü Dergisi } \\
\text { Cilt 4, Say1 1, 96-101, } 2021\end{array}$ & $\begin{array}{r}\text { OKU Journal of Natural and Applied Sciences } \\
\text { Volume 4, Issue 1, 96-101, } 2021\end{array}$ & \\
\hline & $\begin{array}{c}\text { Osmaniye Korkut Ata Üniversitesi } \\
\text { Fen Bilimleri Enstitüsü } \\
\text { Dergisi }\end{array}$ & $\begin{array}{c}\text { Osmaniye Korkut Ata University } \\
\text { Journal of Natural and Applied } \\
\text { Sciences }\end{array}$ & 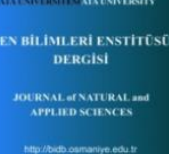 \\
\hline
\end{tabular}

\title{
Makine Öğrenmesi Kullanarak Çağrı Merkezine Gelen Çağrıların Tahmin Edilmesi
}

\section{Mohamed BALLOUCH ${ }^{1}$, Mehmet Fatih AKAY $^{*}$, Sevtap ERDEM ${ }^{3}$, Mesut TARTUK ${ }^{4}$, Taha Furkan NURDAĞ $\breve{g}^{5}$, Hasan Hüseyin YURDAGÜL ${ }^{6}$}

${ }^{1}$ Cukurova University, Engineering Faculty, Computer Engineering, 01330, Adana

${ }^{2}$ Çukurova University, Engineering Faculty, Computer Engineering, 01330, Adana

${ }^{3}$ Çukurova University, Engineering Faculty, Computer Engineering, 01330, Adana

${ }^{4}$ Comdata Group, İstanbul

${ }^{5}$ Comdata Group, İstanbul

${ }^{6}$ Çukurova University, Engineering Faculty, Computer Engineering, 01330, Adana

${ }^{1}$ https://orcid.org/0000-0003-3275-0562

${ }^{2}$ https://orcid.org/0000-0003-0780-0679

${ }^{3}$ https://orcid.org/0000-0002-9332-2070

${ }^{4}$ https://orcid.org/0000-0001-9021-1060

${ }^{5}$ https://orcid.org/0000-0002-0259-2981

${ }^{6}$ https://orcid.org/0000-0002-6866-1644

*Sorumlu yazar: mfakay@cu.edu.tr

\begin{tabular}{|c|c|}
\hline Araştırma Makalesi & ÖZET \\
\hline $\begin{array}{l}\text { Makale Tarihçesi: } \\
\text { Geliş tarihi: } 12 \text { Kasım } 2020 \\
\text { Kabul tarihi:28 Kasım } 2020 \\
\text { Online Yayınlanma: } 2 \text { Mart } 2021\end{array}$ & $\begin{array}{l}\text { Çağrı merkezi, bir kuruluş için çok sayıda telefon görüşmesini idare edebilecek } \\
\text { şekilde donatılmış bir ofistir ve aramaları tahmin etme yeteneği kilit bir } \\
\text { faktördür. Bir şirket, arama sayısını doğru bir şekilde tahmin ederek personel } \\
\text { ihtiyaçlarını planlayabilir, hizmet seviyesi gereksinimlerini karşıllayabilir, } \\
\text { müşteri memnuniyetini artırabilir ve diğer birçok optimizasyondan }\end{array}$ \\
\hline $\begin{array}{l}\text { Anahtar Kelimeler: } \\
\text { Makine Öğrenmesi } \\
\text { Çağrı Merkezi } \\
\text { Tahminleme } \\
\text { Zaman Gecikmesi }\end{array}$ & $\begin{array}{l}\text { yararlanabilir. Bu çalışmada, bir çağrı merkezindeki gelen çağrı sayısını tahmin } \\
\text { etmek için zaman gecikmeleri ile entegreli Çok Katmanlı Algılayıcı (Multilayer } \\
\text { Perceptron - MLP) ve Uzun Kısa Vadeli Bellek (Long-Short Term Memory - } \\
\text { LSTM) tabanlı modeller geliştirilmiştir. 12, 24, } 36 \text { ve 48'lik tahminler üretilip, } \\
\text { tahmin modellerinin performansı Ortalama Mutlak Hata (Mean Absolute Error - } \\
\text { MAE) kullanılarak değerlendirilmiştir. Sonuçlar, MLP tabanlı modellerin MAE } \\
\text { değerlerinin 1,50 ile 13,58 arasında, LSTM tabanlı modellerin ise 19,99 ile } \\
66,74 \text { arasında değiştiğini göstermektedir. }\end{array}$ \\
\hline
\end{tabular}

\section{Forecasting Call Center Arrivals Using Machine Learning}

\begin{tabular}{|c|c|}
\hline Research Article & ABSTRACT \\
\hline $\begin{array}{l}\text { Article History: } \\
\text { Received: } 12 \text { November } 2020 \\
\text { Accepted: } 28 \text { November } 2020 \\
\text { Published online: } 2 \text { March } 2021\end{array}$ & $\begin{array}{l}\text { A call center is an office equipped to handle a large volume of telephone calls } \\
\text { for an organization, for which the ability to forecast calls is a key factor. By } \\
\text { forecasting the number of calls accurately, a company can plan staffing needs, } \\
\text { meet service level requirements, improve customer satisfaction and benefit } \\
\text { from many other optimizations. In this paper, we develop Multilayer Perceptron } \\
\text { (MLP) and Long-Short Term Memory (LSTM) based models combined with } \\
\text { time lags to forecast the number of call arrivals in a call center. We forecast 12, } \\
24,36 \text { and } 48 \text { values ahead and the performance of the forecasting models has } \\
\text { been evaluated using the Mean Absolute Error (MAE). The MLP based model } \\
\text { results show that the MAE values change between 1,50 and 13,58 and LSTM } \\
\text { based model results show that the MAE values change between 19,99 and } \\
66,74 \text {. }\end{array}$ \\
\hline
\end{tabular}

To Cite: Ballouch M., Akay MF., Erdem S., Tartuk M., Nurdağ TF., Yurdagül HH. Forecasting Call Center Arrivals Using Machine Learning. Osmaniye Korkut Ata Üniversitesi Fen Bilimleri Enstitüsü Dergisi 2021; 4(1): 96-101. 


\section{Introduction}

One of the most important concepts that directly affects the growth, success and prestige of companies in today's business world is customer satisfaction. Call centers that have become prominent in the service sector have become the primary communication tool for the majority of companies and companies aim to increase customer satisfaction through call centers.

$60-80 \%$ of a call center budget is allocated on labor costs [1]. Therefore, capacity planning is one of the most important areas for call center performance. Determining the minimum number of agents to achieve the set targets directly affects the profitability and customer satisfaction of the company. Capacity planning is done according to the workload. One of the most significant inputs to the workload is the number of call arrivals. Call arrival indicates the number of calls a call center receives. The call count forecast is mostly exploited to schedule the staff. Companies are interested in the short term forecast to handle the unforeseen and to optimize the staff schedule, and in the long term forecast to hire or assign staff to other tasks. For these reasons, it is very important for companies to make an accurate forecast of the number of call arrivals.

In the last few years, numerous methods have been used to forecast call arrivals in a call center: The number of call arrivals by developing a normal copula model for the arrival process in a call center was forecasted in [2]. Peak call arrivals of rural electric cooperatives call center was forecasted in [3]. They used Gaussian copula for capturing the dependence between non-normal distributions. The number of call arrivals by using artificial neural network was forecasted in [4]. A strategy for selecting a model in call centers was offered in [5]. The strategy was based on flexible loss function, statistical test and economic measure of performance. The number of call arrivals by using a prediction model based on the Elman and Nonlinear Autoregressive Network with Exogenous Inputs (NARX) Neural Network and a back-propagation algorithm was forecasted in [6]. An agent personalized call prediction method that encodes agent skill information as the prior knowledge for call prediction and distribution was proposed in [7]. A data-driven approach to predict an individual customer's call arrival in multichannel customer support centers was used in [8]. A simulation-based machine learning framework to evaluate the performance of call centers having heterogeneous sets of servers and multiple types of demand was used in [9]. Artificial neural networks to forecast the number of call arrivals were used in [10]. Time series statistical and machine learning methods to forecast call volume in a call centre were used in [11]. Call center performance with machine learning was predicted in [12] and call center arrivals at a call center was forecasted using dynamic linear model in [13].

When the related papers in this field are investigated closely, it is observed that integration and optimization of time lags, which is an important concept in time series forecasting, do not appear in any of the studies. Therefore, further studies are needed in this field to explore the effect of time lags in the forecast of call count. The main purpose of this study is to develop MLP and LSTM based models combined with time lags, which can forecast the number of call arrivals, MAE has been used to assess the performance of the models as this metric has been frequently used in literature to assess the performance of models for the forecast of call count.

This paper is structured as follows: Section 2 provides description of the dataset. Section 3 presents the results and discussion. Section 4 concludes the paper.

\section{Dataset Generation}

In this study, we used a data set that has been collected in 15-minute time intervals and obtained from Comdata in Turkey. The data set includes number of call arrivals from 1/1/2018 12:00:00 AM to 11/23/2019 11:45:00 PM. Figure 1 shows the number of calls on a daily basis.

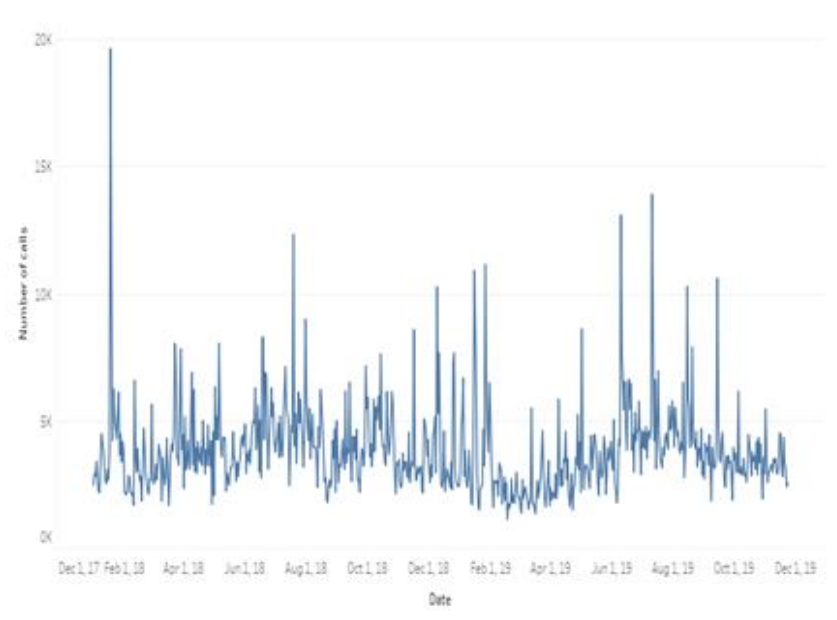

Figure 1. Number of calls on a daily basis 


\section{Results and Discussion}

In this study, 12, 24, 36 and 48 forecast models have been built in order to forecast the number of call arrivals. MLP and LSTM have been utilized to develop the forecast models as these two methods have been found to show superior performance as compared to all other methods for time series forecasting problems in literature. The models have been developed by using different MLP and LSTM hyperparameter values and time lag options.

The forecast strategy that has been used for all models is a recursive strategy, which consists of using a one-step model multiple times where the prediction for the prior time step is used as an input for making a prediction on the following time step.

Finding the best sliding time window for a time specific time series is a very important issue. A sliding time window means a group of time lags which employ to utilize a forecast. The length of the sliding windows is important issue in the forecasting performance. A small window gives limited information to the model. In this study, three rules have been utilized to select sliding windows. The rules of the sliding windows are given below;

- 1 to $\mathrm{N}$ : use all lags starting from 1 till a given value.

- Autocorrelation (AC) > Threshold: use all lags for which the autocorrelation values are above a given threshold.

- Best N AC: use lags which have the highest $\mathrm{N}$ autocorrelation values.

Table 1 and Table 2 show that MLP based forecasting models and results.

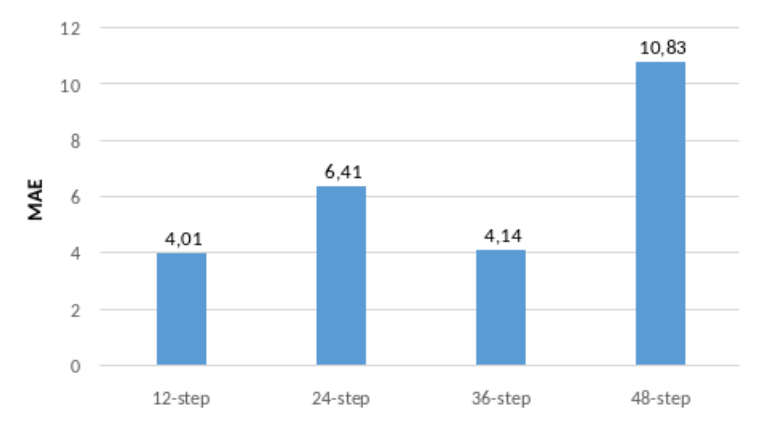

Figure 2. Comparison of the number of forecasts
Table 1. Forecasting models and MAE results

\begin{tabular}{|c|c|c|c|c|c|}
\hline Models & Forecasts & $\begin{array}{c}\text { Time Lag } \\
\text { Option }\end{array}$ & $\begin{array}{c}\text { Hidden } \\
\text { Layer } \\
\text { Neuron } \\
\text { Number }\end{array}$ & $\begin{array}{c}\text { Selected } \\
\text { Time Lags }\end{array}$ & MAE \\
\hline $\begin{array}{c}\text { Model } \\
1\end{array}$ & 12 & $\begin{array}{l}\text { Best } 10 \\
\text { AC }\end{array}$ & 13 & $\begin{array}{c}1,2,3,4 \\
5,6,7,8,9 \\
10\end{array}$ & 4,95 \\
\hline Model 2 & 12 & Best $20 \mathrm{AC}$ & 5 & $\begin{array}{c}1,2,3,4 \\
5,6,7,8,9 \\
10,12,95 \\
96,97,98 \\
99,100 \\
193,194\end{array}$ & 1,37 \\
\hline $\begin{array}{c}\text { Model } \\
3\end{array}$ & 12 & $\mathrm{AC}>0,7$ & 15 & $1,2,3,10$ & 4,72 \\
\hline $\begin{array}{c}\text { Model } \\
4\end{array}$ & 12 & $\mathrm{AC}>0,8$ & 13 & 1,2 & 5,05 \\
\hline $\begin{array}{l}\text { Model } \\
5\end{array}$ & 12 & 1 to $\mathrm{n}$ & 6 & 1 to 8 & 2,29 \\
\hline $\begin{array}{c}\text { Model } \\
6\end{array}$ & 12 & 1 to $\mathrm{n}$ & 6 & 1 to 16 & 5,67 \\
\hline $\begin{array}{l}\text { Model } \\
7\end{array}$ & 24 & $\begin{array}{l}\text { Best } 10 \\
\text { AC }\end{array}$ & 9 & $\begin{array}{c}1,2,3,4 \\
5,6,7,8,9 \\
10\end{array}$ & 3,77 \\
\hline Model 8 & 24 & Best $20 \mathrm{AC}$ & 9 & $\begin{array}{c}1,2,3,4 \\
5,6,7,8,9 \\
10,12,95 \\
96,97,98 \\
99,100 \\
193,194\end{array}$ & 3,07 \\
\hline $\begin{array}{l}\text { Model } \\
9\end{array}$ & 24 & $\mathrm{AC}>0,7$ & 6 & $1,2,3,10$ & 10,90 \\
\hline $\begin{array}{c}\text { Model } \\
10\end{array}$ & 24 & $\mathrm{AC}>0,8$ & 6 & 1,2 & 8,43 \\
\hline $\begin{array}{c}\text { Model } \\
11\end{array}$ & 24 & 1 to $\mathrm{n}$ & 13 & 1 to 8 & 8,71 \\
\hline $\begin{array}{l}\text { Model } \\
12\end{array}$ & 24 & 1 to $\mathrm{n}$ & 13 & 1 to 16 & 3,55 \\
\hline
\end{tabular}

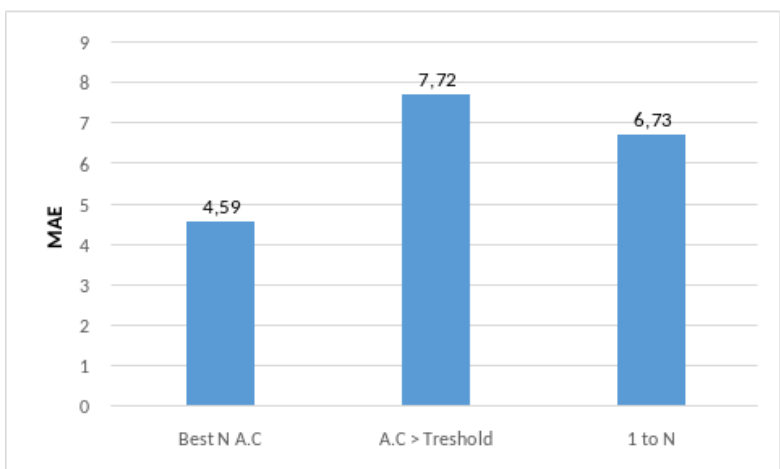

Figure 3. Comparison of time lag options 
Table 2. Forecasting models and MAE results

\begin{tabular}{|c|c|c|c|c|c|}
\hline Models & Forecasts & $\begin{array}{c}\text { Time } \\
\text { Lag } \\
\text { Option }\end{array}$ & $\begin{array}{c}\text { Hidden } \\
\text { Layer } \\
\text { Neuron } \\
\text { Number } \\
\end{array}$ & $\begin{array}{l}\text { Selected } \\
\text { Time Lags }\end{array}$ & MAE \\
\hline Model & & Best 10 & & $1,2,3,4$ & \\
\hline 13 & 24 & $\mathrm{AC}$ & 35 & $\begin{array}{c}5,6,7,8,9 \\
10\end{array}$ & 4,32 \\
\hline $\begin{array}{c}\text { Model } \\
14\end{array}$ & 36 & $\begin{array}{l}\text { Best } 20 \\
\text { AC }\end{array}$ & 35 & $\begin{array}{c}1,2,3,4, \\
5,6,7,8,9, \\
10,12,95, \\
96,97,98, \\
99,100, \\
193,194\end{array}$ & 3,18 \\
\hline $\begin{array}{c}\text { Model } \\
15\end{array}$ & 36 & $\begin{array}{c}\mathrm{AC}> \\
0,7\end{array}$ & 17 & $1,2,3,10$ & 5,52 \\
\hline $\begin{array}{c}\text { Model } \\
16\end{array}$ & 36 & $\begin{array}{c}\mathrm{AC}> \\
0,8\end{array}$ & 17 & 1,2 & 3,73 \\
\hline $\begin{array}{c}\text { Model } \\
17\end{array}$ & 36 & 1 to $n$ & 20 & 1 to 8 & 3,87 \\
\hline $\begin{array}{c}\text { Model } \\
18\end{array}$ & 36 & 1 to $\mathrm{n}$ & 20 & 1 to 16 & 4,22 \\
\hline $\begin{array}{c}\text { Model } \\
19\end{array}$ & 48 & $\begin{array}{c}\text { Best } 10 \\
\text { AC }\end{array}$ & 30 & $\begin{array}{c}1,2,3,4 \\
5,6,7,8,9 \\
10\end{array}$ & 10,96 \\
\hline $\begin{array}{c}\text { Model } \\
20\end{array}$ & 48 & $\begin{array}{c}\text { Best } 20 \\
\text { AC }\end{array}$ & 30 & $\begin{array}{c}1,2,3,4, \\
5,6,7,8,9 \\
10,12,95, \\
96,97,98, \\
99,100, \\
193,194\end{array}$ & 5,12 \\
\hline $\begin{array}{c}\text { Model } \\
21\end{array}$ & 48 & $\begin{array}{c}\mathrm{AC}> \\
0,7\end{array}$ & 5 & $1,2,3,10$ & 9,83 \\
\hline $\begin{array}{c}\text { Model } \\
22\end{array}$ & 48 & $\begin{array}{c}\mathrm{AC}> \\
0,8\end{array}$ & 10 & 1,2 & 13,59 \\
\hline $\begin{array}{c}\text { Model } \\
23\end{array}$ & 48 & 1 to $n$ & 5 & 1 to 8 & 12,99 \\
\hline $\begin{array}{c}\text { Model } \\
24\end{array}$ & 48 & 1 to $n$ & 11 & 1 to 16 & 12,53 \\
\hline
\end{tabular}

It can be seen from Figure 2 that forecasting the next 12 values yields lower error rates as opposed to the other values. The arithmetical mean of the MAE values for the 12-step is 4,01 while the mean value is 6,41 for 24 -step, 4,14 for 36-step and 10,83 for 48-step. According to the MAE's given in Figure 3, between the three options of selecting time lags, the arithmetical mean MAE for the first option (i.e. Best N AC) has been calculated as 4,59, for the second option (i.e. AC $>$ Threshold) the mean value is 7,72 and finally the mean value for the third option (i.e. 1 to $\mathrm{N}$ ) is 6,73 . By comparing these options of time lags, one can say that Best N AC option gives more accurate results than other options.

Table 3 and Table 4 show LSTM based forecasting models and results.

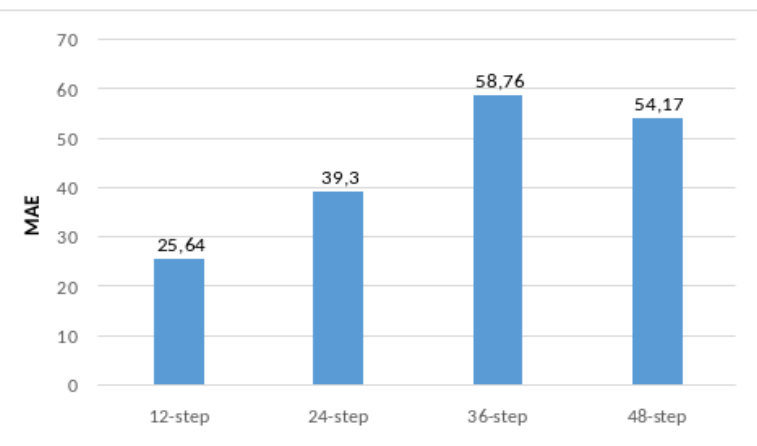

Figure 4. Comparison of the number of forecasts

Table 3. Forecasting models and MAE results

\begin{tabular}{|c|c|c|c|c|c|}
\hline Models & Forecasts & $\begin{array}{c}\text { Time Lag } \\
\text { Option }\end{array}$ & $\begin{array}{c}\text { Hidden } \\
\text { Layer } \\
\text { Neuron } \\
\text { Number }\end{array}$ & $\begin{array}{l}\text { Selected } \\
\text { Time Lags }\end{array}$ & MAE \\
\hline Model & & Best 10 & & $1,2,3,4$ & \\
\hline 1 & 12 & $\mathrm{AC}$ & 13 & $\begin{array}{c}5,6,7,8,9 \\
10\end{array}$ & 19,99 \\
\hline Model 2 & 12 & Best $20 \mathrm{AC}$ & 5 & $\begin{array}{c}1,2,3,4 \\
5,6,7,8,9 \\
10,12,95 \\
96,97,98 \\
99,100 \\
193,194\end{array}$ & 24,31 \\
\hline $\begin{array}{c}\text { Model } \\
3\end{array}$ & 12 & $\mathrm{AC}>0,7$ & 15 & $1,2,3,10$ & 31,8 \\
\hline $\begin{array}{c}\text { Model } \\
4\end{array}$ & 12 & $\mathrm{AC}>0,8$ & 13 & 1,2 & 27,37 \\
\hline $\begin{array}{l}\text { Model } \\
5\end{array}$ & 12 & 1 to $n$ & 6 & 1 to 8 & 24,04 \\
\hline $\begin{array}{c}\text { Model } \\
6\end{array}$ & 12 & 1 to $n$ & 6 & 1 to 16 & 26,34 \\
\hline Model & & Best 10 & & $1,2,3,4$ & \\
\hline 7 & 24 & $\mathrm{AC}$ & 9 & $\begin{array}{c}5,6,7,8,9 \\
10\end{array}$ & 46,18 \\
\hline Model 8 & 24 & Best $20 \mathrm{AC}$ & 9 & $\begin{array}{c}1,2,3,4, \\
5,6,7,8,9, \\
10,12,95 \\
96,97,98 \\
99,100 \\
193,194\end{array}$ & 38 \\
\hline $\begin{array}{c}\text { Model } \\
9\end{array}$ & 24 & $\mathrm{AC}>0,7$ & 6 & $1,2,3,10$ & 31,33 \\
\hline $\begin{array}{l}\text { Model } \\
10\end{array}$ & 24 & $\mathrm{AC}>0,8$ & 6 & 1,2 & 36,29 \\
\hline $\begin{array}{c}\text { Model } \\
11\end{array}$ & 24 & 1 to $n$ & 13 & 1 to 8 & 46,04 \\
\hline $\begin{array}{c}\text { Model } \\
12\end{array}$ & 24 & 1 to $n$ & 13 & 1 to 16 & 38,02 \\
\hline
\end{tabular}

It can be seen from Figure 4 that forecasting the next 12 values yields lower error rates as opposed to the other values. The arithmetical mean of the MAE values for the 12-step is 25,64 while the mean value is 39,30 for 24 -step, 58,76 for 36-step and 64,17 for 48-step. According to the MAE's given in Figure 5, between the three options of 
selecting time lags, the arithmetical mean MAE for the first option (i.e. Best N AC) has been calculated as 42,72, for the second option (i.e. AC $>$ Threshold) the mean value is 43,79 and finally the mean value for the third option (i.e. 1 to $\mathrm{N}$ ) is 44,46 . By comparing these options of time lags, one can say that Best $\mathrm{N}$ AC option gives more accurate results than other options.

Table 4. Forecasting models and MAE results

\begin{tabular}{|c|c|c|c|c|c|}
\hline Models & Forecasts & $\begin{array}{c}\text { Time Lag } \\
\text { Option }\end{array}$ & $\begin{array}{c}\text { Hidden } \\
\text { Layer } \\
\text { Neuron } \\
\text { Number }\end{array}$ & $\begin{array}{c}\text { Selected } \\
\text { Time Lags }\end{array}$ & MAE \\
\hline Model & & Best 10 & & $1,2,3,4$ & \\
\hline 13 & 24 & $\mathrm{AC}$ & 35 & $\begin{array}{c}5,6,7,8,9 \\
10\end{array}$ & 39,25 \\
\hline $\begin{array}{c}\text { Model } \\
14\end{array}$ & 36 & Best $20 \mathrm{AC}$ & 35 & $\begin{array}{c}1,2,3,4 \\
5,6,7,8,9, \\
10,12,95, \\
96,97,98 \\
99,100 \\
193,194\end{array}$ & 50,72 \\
\hline $\begin{array}{c}\text { Model } \\
15\end{array}$ & 36 & $\mathrm{AC}>0,7$ & 17 & $1,2,3,10$ & 66,74 \\
\hline $\begin{array}{c}\text { Model } \\
16\end{array}$ & 36 & $\mathrm{AC}>0,8$ & 17 & 1,2 & 60,14 \\
\hline $\begin{array}{c}\text { Model } \\
17\end{array}$ & 36 & 1 to $n$ & 20 & 1 to 8 & 54,41 \\
\hline $\begin{array}{c}\text { Model } \\
18\end{array}$ & 36 & 1 to $n$ & 20 & 1 to 16 & 61,78 \\
\hline $\begin{array}{c}\text { Model } \\
19\end{array}$ & 48 & $\begin{array}{c}\text { Best } 10 \\
\text { AC }\end{array}$ & 30 & $\begin{array}{c}1,2,3,4 \\
5,6,7,8,9 \\
10\end{array}$ & 58,68 \\
\hline $\begin{array}{c}\text { Model } \\
20\end{array}$ & 48 & Best $20 \mathrm{AC}$ & 30 & $\begin{array}{c}1,2,3,4 \\
5,6,7,8,9 \\
10,12,95 \\
96,97,98 \\
99,100 \\
193,194\end{array}$ & 64,61 \\
\hline $\begin{array}{c}\text { Model } \\
21\end{array}$ & 48 & $\mathrm{AC}>0,7$ & 5 & $1,2,3,10$ & 50,4 \\
\hline $\begin{array}{c}\text { Model } \\
22\end{array}$ & 48 & $\mathrm{AC}>0,8$ & 10 & 1,2 & 46,22 \\
\hline $\begin{array}{c}\text { Model } \\
23\end{array}$ & 48 & 1 to $n$ & 5 & 1 to 8 & 54,7 \\
\hline $\begin{array}{c}\text { Model } \\
24\end{array}$ & 48 & 1 to $n$ & 11 & 1 to 16 & 50,4 \\
\hline
\end{tabular}

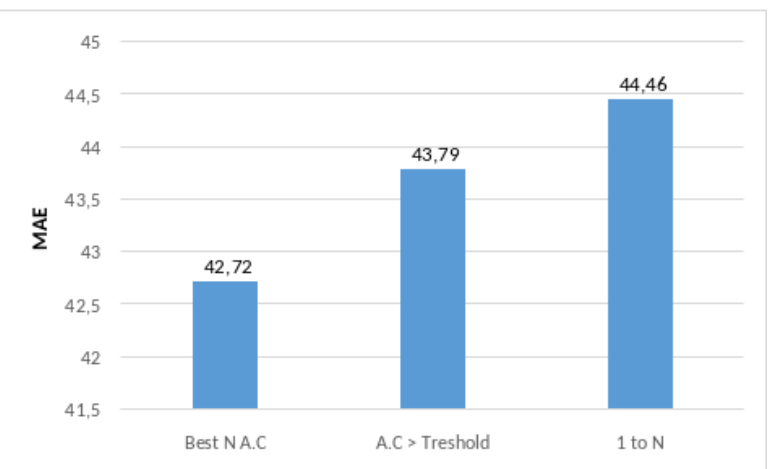

Figure 5. Comparison of time lag options

MLP based models yield lower MAE's than that of LSTM based models. This is due to the fact that LSTM did not integrate well with the time lags and therefore could not capture the dependencies between the subsequent calls.

\section{Conclusion}

Among all the models that were developed in this study, a total number of three options have been used for determining the time lags. According to the results, MLP-based models give better results than LSTM-based models and it has been observed that the changes of the time lags options used in the forecasting models change the forecasting MAE significantly. The most favorable option appears as "Best N AC", and the least favorable option is "AC > Threshold". According to those observations, we concluded that the usage of data set autocorrelations plays important role in finding the optimal time lags values.

\section{Statement of Conflict of Interest}

Authors have declared no conflict of interest.

\section{Author's Contributions}

The contribution of the authors is equal

\section{Acknowledgment}

The authors would like to thank Çukurova University Scientific Research Projects Center for supporting this work. (Project no: FBA-202012962)

\section{References}

[1] Mehrotra V., Ozlük O., Saltzman R. Intelligent procedures for intra-day updating of call center agent schedules, Production and Operations Management 2010; 19(3): 353-367. 
[2] Channouf N., L'Ecuyer P. A normal copula model for the arrival process in a call center, International Transactions in Operational Research 2012; 19(6): 771-787.

[3]

[4] Kim T., Kenkel P., Brorsen BW. Forecasting hourly peak call volume for a rural electric cooperative call center, Journal of Forecasting 2012; 31(4): 314329.

[5] Millán-Ruiz D., Hidalgo JI. Forecasting call centre arrivals, Journal of Forecasting 2013; 32(7): 628-638.

[6] Bastianin A., Galeotti M., Manera M. Statistical and economic evaluation of time series models for forecasting arrivals at call centers, Empirical Economics 2016; 1-33.

[7] Jalal ME., Hosseini M., Karlsson S. Forecasting incoming call volumes in call centers with recurrent neural networks, Journal of Business Research 2016; 69(11): 4811-4814.

[8] Mohammed RA. Using personalized model to predict traffic jam in inbound call center. EAI Endorsed Transactions on Scalable Information Systems 2017; 4(12): 1-6.

[9] Moazeni S., Andrade R. A data-driven approach to predict an individual customer's call arrival in multichannel customer support centers, 2018 IEEE International Congress on Big Data (BigData Congress), 2018, San Francisco, CA, pp. 66-73.

[10] Li S., Wang Q., Koole G. Predicting call center performance with machine learning, In INFORMS International Conference on Service Science 2018; 193-199.

[11] Barrow D., Kourentzes N. The impact of special days in call arrivals forecasting: A neural network approach to modelling special days, European Journal of Operational Research 2018; 264(3): 967977.

[12] Baldon N. Time series forecast of call volume in call centre using statistical and machine learning methods, $\mathrm{PhD}$ Thesis, KTH Royal Institute of Technology, Stockholm, Sweden, 2019.
[13] Li S., Qingchen W., Ger K. Predicting call center performance with machine learning, INFORMS International Conference on Service Science. Springer, Cham, 2018.

[14] Yamamato K., Hatayama G. Forecasting call center arrivals at call center using dynamic linear model, Omron Technics 2019; 50: 1-7. 